\title{
PEMBINAAN IMTAK DALAM MENINGKATKAN PERILAKU PROSOSIAL PESERTA DIDIK DI SMP NEGERI 3 PALU
}

\author{
Darmawansyah \\ Dosen Fakultas Tarbiyah dan Ilmu Keguruan IAIN Palu \\ darmawansyah@iainpalu.ac.id
}

\begin{abstract}
Abstrack
The study discusses coaching in improving the prosocial behavior of students at SMP Negeri 3 Palu. The research method used is descriptive qualitative research method. The research data were collected through observation, interview, and documentation techniques. Furthermore, it is analyzed by reducing data, presenting data and verifying data. In order to ensure the validity and credibility of the data obtained, the validity of the data is checked. Research results: (1). The form of implementing faith and piety in improving the prosocial behavior of students at SMP Negeri 3 Palu is carried out in several areas of program activities, namely; education, religion, and hygiene. (2) Supporting factors for fostering faith and piety in improving the prosocial behavior of students at SMP Negeri 3 Palu, namely the compatibility between the goals of fostering faith and piety with the goals of the school, great attention from teachers to students, and the availability of adequate facilities and infrastructure. . The inhibiting factors faced include the lack of time availability, the very diverse character differences of students, and the unstoppable development of technological flows.
\end{abstract}

Keyword: faith and piety, prosocial behavior.

Abstrak

Penelitian membahas tentang pembinaan dalam meningkatkan perilaku prososial peserta didik di SMP Negeri 3 Palu. Metode penelitian yang digunakan adalah metode penelitian deskriptif kualitatif. Data penelitian dikumpulkan melalui teknik observasi, interview, dan dokumentasi. Selanjutnya dianalisis dengan cara mereduksi data, penyajian data dan verifikasi data. Agar data yang diperoleh terjamin validitas dan kredibilitasnya maka diadakan pengecekan keabsahan data. Hasil penelitian: (1). bentuk pelaksanaan pembinaan iman dan takwa dalam meningkatkan perilaku prososial peserta didik di SMP Negeri 3 Palu dilaksanakan dalam beberapa bidang program kegiatan yakni; bidang pendidikan, bidang keagaaman, bidang kebersihan. (2) Faktor pendukung pembinaan iman dan takwa dalam meningkatkan perilaku prososial peserta didik di SMP Negeri 3 Palu yakni adanya kesesuaian antara tujuan pembinaan iman dan takwa dengan tujuan sekolah, adanya perhatian yang besar dari guru kepada peserta didik, serta 
tersedianya sarana dan prasarana yang memadai. Adapun faktor penghambat yang dihadapi antara lain karena kurangnya ketersediaan waktu, adanya perbedaan karakter peserta didik yang sangat beragam, serta faktor perkembangan arus teknologi yang tak terbendung.

Kata kunci: iman dan takwa, perilaku prososial

\section{Pendahuluan}

Kemajuan ilmu pengetahuan dan teknologi mempercepat perubahan dalam semua ruang aspek kehidupan manusia, kemajuan tersebut harus disikapi dengan baik oleh setiap individu karena kemajuan tersebut akan berdampak pada kemerosotan nilai-nilai budaya, moral, dan nilai-nilai religius yang dianut oleh suatu kelompok masyarakat tertentu.

Salah satu dampak negatif dari kemajuan teknologi saat ini adalah kemerosotan nilai-nilai perilaku prososial terutama pada kalangan remaja yang notabene mereka adalah para pelajar. Berbagai penyimpangan-penyimpangan yang sering dilakukan oleh para pelajar seperti, tawuran, mabuk-mabukan, seks bebas sampai pada pembunuhan.

Kondisi tersebut di atas haruslah menjadi perhatian serius dari para orang tua selaku pendidik utama yang bertugas menanamkan nilai-nilai religius khususnya nilainilai keimanan dan ketakwaan kepada anak-anak. Pendidik di sekolah juga harus bertanggung jawab meminimalisir penyimpangan-penyimpangan tersebut untuk menghasilkan generasi muda yang berkualitas baik dari segi keilmuan maupun dari segi akhlak atau perilaku yang baik.

Pembinaan iman dan takwa peserta didik dan remaja pada umumnya membutuhkan ketekunan, kesabaran dan kerja sama semua pihak. Begitu pula sistem dan strategi pendidikan perlu terus dikembangkan. Hal ini disebabkan karena kuatnya pengaruh perkembangan teknologi informasi yang melanda hampir seluruh daratan dunia saat ini. Sistem nilai lama secara bertahap akan diganti dengan nilai-nilai baru yang akan merusak sistem nilai yang selama ini dipandang sebagai nilai luhur bangsa Indonesia.

Pembinaan iman dan takwa bagi peserta didik adalah sebuah keniscayaan, karena mereka adalah aset bangsa pada masa mendatang yang akan mengambil alih estafet kepemimpinan dan menjadi tenaga penggerak pembangunan bangsa. Kualitas iman dan takwa bangsa pada masa yang akan datang dapat dilihat pada kualitas remaja yang ada sekarang. Oleh karena itu, perlu diusahakan sistem pembinaan terarah dan terpadu terhadap semua peserta didik di setiap jenis dan jenjang pendidikan.

Pembinaan iman dan takwa bagi peserta didik selain diharapkan dapat meningkatkan pengetahuan atau kecerdasan religius juga diharapkan dapat menjadi pondasi awal dalam diri peserta didik tersebut dalam bertindak dan berperilaku dalam kehidupan sehari-hari. Dengan demikian dalam bertindak dan berperilaku tercermin nilai-nilai perilaku prososial dari peserta didik itu sendiri, dimana nilai-nilai perilaku prososial tersebut menjadi suatu keharusan dalam kehidupan manusia sebagai makhluk sosial.

Sebagai makhluk sosial, manusia mempunyai hubungan dengan lingkungan sekitarnya. Karena itu, manusia memiliki dorongan untuk mengabdi kepada 
masyarakat. ${ }^{1}$ Sebagai makhluk sosial, manusia dengan tindakan-tindakannya harus mencerminkan perilaku yang dapat menolong orang lain, mampu melakukan kerjasama, jujur, dapat melakukan tenggang rasa, memperhatikan hak dan kesejahteraan bersama serta punya rasa kepedulian terhadap orang lain. Dalam kehidupan sehari-hari, manusia tidak bisa lepas dari tolong menolong serta mempunyai kepedulian terhadap orang lain. Menurut Faturrohman "setinggi apapun kemandirian seseorang, pada saat-saat tertentu, dia akan membutuhkan orang lain". 2 Tujuan dari prososial dalam bidang pendidikan adalah untuk menciptakan hubungan yang erat dalam menjalin dan memelihara keharmonisan serta hubungan baik dengan orang lain. Hubungan baik tersebut terlihat dalam bentuk menolong guru maupun teman-teman di lingkungan sekolah, terbentuknya sikap saling tolong menolong tersebut menciptakan perilaku yang baik dan perilaku yang baik itu dapat diterapkan di dalam kelas.

\section{Metode Penelitian}

Jenis penelitian ini adalah penelitian kualitatif. Metode penelitian kualitatif sering juga disebut metode penelitian naturalistik karena penelitiannya dilakukan pada kondisi yang alamiah (natural setting), disebut juga metode etnographi, karena pada awalnya metode ini lebih banyak digunakan untuk penelitian bidang antropologi budaya, disebut sebagai metode kualitatif karena data yang terkumpul dan analisanya lebih bersifat kualitatif

Penelitian ini menggunakan metode penelitian deskriptif kualitatif. Metode yang dimaksud adalah penelitian yang mengandalkan manusia sebagai alat penelitian, sehingga penulis dapat menemukan kepastian dan keaslian data untuk diuraikan sebagai hasil penelitian yang akurat. Penelitian yang bersifat deskriptif menurut Suharsimi Arikunto "lebih tepat apabila menggunakan pendekatan kualitatif". ${ }^{3}$

Penelitian ini lebih menitik beratkan kepada kegiatan penelitian di lokasi objek. Sehingga dalam penelitian ini nantinya tidak dibutuhkan lagi hipotesis yang sifatnya menduga-duga atau meraba-raba berbagai hal yang menyangkut peranan pembinaan iman dan takwa dalam meningkatkan perilaku prososial peserta didik di SMP Negeri 3 Palu.

\section{Hasil dan Pembahasan}

\section{Pembinaan dalam Bidang Pendidikan}

Bentuk-bentuk pembinaan iman dan takwa yang dilaksanakan oleh civitas akademik SMP Negeri 3 Palu kepada peserta didik tidak dilepaskan dari kegiatan pendidikan itu sendiri, meskipun sebenarnya masih ada keterkaitan antara bentuk pembinaan iman dan takwa dalam bidang keagamaan. Bentuk pembinaan tersebut seperti pembinaan baca tulis Alqur'an untuk lebih memperkuat pemahaman dan pengamalan keagamaan peserta didik, sehingga ketika peserta didik telah mampu membaca ayat-ayat suci Alqur'an dengan baik, mereka juga diharapkan mampu memahami makna yang terkandung dari ayat-ayat tersebut, sehingga peserta didik

\footnotetext{
${ }^{1}$ Bimo Walgito, Psikologi Sosial (Suatu Pengantar), (Cet. IV; Yogyakarta: Andi Offset 2003), 26. ${ }^{2}$ Faturrohman, Pengantar Psikologi Sosial, (Yogyakarta: Pustaka 2009), 14.

${ }^{3}$ Suharsimi Arikunto, Prosedur Penelitian Ilmiah, Suatu Pendekatan Peraktek, (Cet. IX; Jakarta: Rineka Cipta, 1993), 209.
} 
tidak hanya sampai pada batas memahami saja tetapi juga mampu mengaplikasikan dalam kehidupan sehari-hari. Oleh karena itu, di SMP Negeri 3 Palu peserta didik dibiasakan untuk membaca ayat-ayat suci Alqur'an setiap pagi sebelum jam pelajaran dimulai dan pelatihan baca tulis Alqur'an setelah jam pelajaran selesai.

Dengan dapat membaca Alqur'an secara fasih, maka peserta didik akan mudah untuk memahami makna yang terkandung di dalamnya sehingga mereka dapat mengaktualisasikan dalam sikap dan perilaku sehari-hari, dimana hal ini akan berimplikasi terhadap peningkatan perilaku prososial dari peserta didik itu sendiri.

\section{Pembinaan dalam Bidang Keagamaan}

Bentuk pembinaan dalam bidang keagamaan yang dilaksanakan oleh SMP Negeri 3 Palu, bertujuan tidak lain untuk meningkatkan keimanan dan ketakwaan peserta didik kepada Allah swt. Bentuk pembinaan ini diwujudkan dalam bentuk pelaksanaan kegiatan shalat dzuhur secara berjamaah setiap harinya di mana sebelum pelaksanaan shalat terlebih dahulu diawali oleh siraman rohani yakni kultum yang dibawakan oleh peserta didik itu sendiri.

Kegiatan keagamaan yang lain yang dilaksanakan di SMP Negeri 3 Palu selain pelaksanaan shalat secara berjamaah tersebut yakni kegiatan amaliah ramadhan yang dilaksanakan pada tiap datangnya bulan suci ramadhan. Hal ini dimaksudkan agar peserta didik kembali fitri, memperkaya wawasan keagamaan, membentuk perilaku positif peserta didik yang akan berimplikasi secara langsung terhadap peningkatan perlaku prososial yang ada dalam diri tiap-tiap peserta didik, yang memungkinkan bagi mereka untuk saling tolong menolong, saling menghargai, serta saling berbagi dengan orang-orang yang ada di sekitarnya.

Peserta didik mengakui dengan adanya pembinaan dalam bidang keagamaan ini telah memberikan manfaat yang sangat besar bagi mereka. Diantara manfaat itu yakni, mereka semakin dapat untuk saling menghargai antara satu dengan yang lain, tumbuh rasa kebersamaan yang kuat di dalam diri mereka, menumbuhkan sikap saling tolong menolong, membuat mereka dapat mengerti posisi orang lain, dimana kesemuanya ini tidak hanya terjalin bagi peserta didik yang memiliki keyakinan atau kepercaayaan yang sama, tetapi juga terjalin bagi peserta didik yang memiliki latar belakang kepercayaan dan keyakinan yang berbeda.

\section{Pembinaan dalam Bidang Kebersihan}

Masalah kebersihan masih memiliki keterkaitan dengan kedua bidang sebelumnya yakni bidang pendidikan dan keagamaan, karena kebersihan adalah merupakan salah satu ajaran Islam yang sangat penting untuk diterapkan baik kebersihan jasmani maupun kebersihan rohani. Kebersihanpun merupakan tandatanda keimanan dan ketakwaan seseorang.

Civitas akademika SMP Negeri 3 Palu menyadari bahwa selain merupakan tuntutan agama, kebersihan pun turut mendukung pelaksanaan pembelajaran yang sehat sehingga peserta didik dapat belajar dengan tenang. Hasil pengamatan yang Peneliti jumpai di lokasi yakni selain program kerja bakti yang dilakukan pada setiap hari Sabtu, program kebersihan sebenarnya telah diterapkan pada setiap kelas yang dikoordinir oleh ketua kelas dan diawasi oleh guru wali kelas masing-masing. 


\section{Pembinaan pada Bidang Olahraga dan Kesenian}

Kegiatan-kegiatan yang termasuk dalam bidang olahraga dan kesenian merupakan kerjasama pihak sekolah dengan pengurus OSIS untuk mengalihkan perhatian peserta didik dari kegiatan-kegiatan negatif yang tidak bermanfaat, kepada kegiatan-kegiatan yang memupuk kerjasama, solidaritas, dan rasa kekeluargaan.

Upaya pembinaan iman dan takwa peserta didik untuk meningkatkan perilaku prososial mereka, salah satunya dilakukan melalui kegiatan yang bermanfaat dalam bidang olahraga dan kesenian (keterampilan). Melalui kegiatan ini diharapkan dapat memupuk rasa kerjasama dan sportifitas dari tiap-tiap peserta didik yang ada sebagai cerminan dari sikap prososial yang baik.

\section{Kesimpulan}

Pelaksanaan pembinaan iman dan takwa untuk meningkatkan perilaku prososial peserta didik di SMP Negeri 3 Palu dilaksanakan dalam beberapa bentuk, yaitu pembinaan dalam bidang pendidikan, bidang keagamaan, bidang kebersihan, serta bidang olahraga dan kesenian. Pembinaan iman dan takwa ini memiliki peranan yang sangat besar terhadap perilaku prososial peserta didik, karena dengan adanya pemahaman iman dan takwa yang baik dalam diri peserta didik, maka peserta didik akan mengetahui bahwa hidup harus selaras antara ibadah kepada Allah dan berbuat baik dengan sesama manusia.

\section{Daftar Pustaka}

Arikunto, Suharsimi, Prosedur Penelitian Ilmiah, Suatu Pendekatan Peraktek, Jakarta: Rineka Cipta, 1993.

Daud, Muhammad Ali, Pendidikan Agama Islam, Jakarta: PT. Raja Grafindo Persada, 2002.

Dayakisni, Tri dan Hudaniah, Psikologi Sosial, Malang: UMM Press, 2003.

Desmita, Psikologi Perkembangan Peserta Didik, Bandung: Remaja Rosda Karya, 2009.

Faturrohman, Pengantar Psikologi Sosial, (Yogyakarta: Pustaka 2009),

Ginanjar, Ary Agustian, Rabasia Membangun Kecerdasan Emosi dan Spritual, Jakarta: PT Arga, 2008.

Hamid, Zuhri, Bertakwa Menurut Syariat Islam, Yogyakarta: Dua Dimensi, 1985.

Helmy, Masdar, Dakwah dalam Alam Pembangunan, Semarang: Toha Putra, 1976.

Soekanto, Sosiologi Suatu Pengantar, Jakarta: PT. Raja Grafindo Persada, 2003.

Walgito, Bimo, Psikologi Sosial (Suatu Pengantar), Yogyakarta: Andi Offset, 2003. 